\title{
The distribution and conservation status of marine turtles in The Gambia, West Africa: a first assessment
}

\author{
Linda K. Barnett, Craig Emms, Alpha Jallow, Anna Mbenga Cham and Jeanne A. Mortimer
}

\begin{abstract}
This paper reports the first systematic survey of the marine turtles of the $80 \mathrm{~km}$ of Gambian coastline, and brings together new data and all past records and reports of marine turtles in The Gambia. Green turtles Chelonia mydas are the most abundant turtles and this is the only species so far observed nesting in The Gambia, with peak nesting between August and October. Although $75 \%$ ( $60 \mathrm{~km}$ ) of The Gambian coastline appears to be suitable for turtle nesting, most nesting activity is confined to the southern coastline. Offshore foraging habitat is apparently extensive. Strandings of green turtles, olive ridley turtles Lepidochelys olivacea, leatherback turtles Dermochelys coriacea and hawksbill turtles Eretmochelys imbricata have been recorded, but we were
\end{abstract}

unable to find evidence for loggerhead turtles Caretta caretta. Threats are mainly of human origin, and include illegal harvesting of eggs, juveniles and adults, as well as mortality as fisheries bycatch, including trawling. One stranded green turtle apparently had fibropapilloma disease. The major threat to nesting habitats is erosion and unregulated development of the coast for tourism. Marine turtles are fully protected under Gambian law. Other national efforts to conserve turtles in The Gambia are described and assessed.

Keywords Africa, conservation status, nesting, marine turtles, The Gambia, threats.

\section{Introduction}

The biology and conservation status of marine turtle populations in The Gambia are poorly documented. The lack of information is partly due to the absence of local turtle specialists and the lack of research resources and infrastructure. Previously available information is limited to a brief study by Gruschwitz et al. (1991), information compiled by UNEP/CMS (1999a, b) and Fretey (2001) and local unpublished reports.

In response to this, we undertook a study to provide baseline information on the marine turtles of The Gambia. Our aims were to collate past records and data, evaluate the availability of marine turtle foraging and nesting habitats, nesting distribution and seasonality, and assess threats to and current legislation pertaining to

\footnotetext{
Linda K. Barnett ${ }^{1}$ (Corresponding author), Craig Emms ${ }^{1}$ and Alpha Jallow Department of Parks and Wildlife Management, Department of State for Fisheries, Natural Resources and the Environment, State House, Banjul, The Gambia. E-mail drumohq@qanet.gm

Anna Mbenga Cham Department of Fisheries, P.O. Box 206, Banjul, The Gambia.

Jeanne A. Mortimer Department of Zoology, University of Florida, Gainesville, Florida, USA.

${ }^{1}$ Present address: Makasutu Wildlife Trust, P.O. Box 2164, Serrekunda, The Gambia.

Received 6 August 2002. Revisions requested 13 March 2003 Accepted 20 June 2003
}

marine turtles in The Gambia, and the conservation measures being taken to protect them.

The Gambia became a signatory to the Abidjan Memorandum in 1999. The memorandum provides a basis for the regional conservation of marine turtles of the Atlantic Coast of Africa. For effective management and conservation measures to be put into place, however, accurate and up to date information is needed from all participating countries. This study is a first response to this requirement for The Gambia, to enable it to participate in and contribute to the conservation of marine turtles in West Africa.

\section{Study area}

The Gambia is a small West African country bordered on three sides by its larger neighbour, Senegal, and on its west side by the Atlantic Ocean along $80 \mathrm{~km}$ of coastline (Government of The Gambia, 1999a). The Gambia is the fourth most densely populated country in Africa, with a total land area of only c. $11,300 \mathrm{~km}^{2}$ but with a large human population $(1,038,175$ people in 1993) and an annual growth rate of $4.2 \%$ per annum (Fatty et al., 1997).

The mouth of the River Gambia bisects the coastline into two parts (Fig. 1), the North Bank with $11 \mathrm{~km}$ of coastline and the South Bank with $69 \mathrm{~km}$ (ECOLAS, 2000). Most of the coastline is undeveloped, except for widely scattered fishing villages and a few beach bars catering to tourists. The tourist industry is currently 


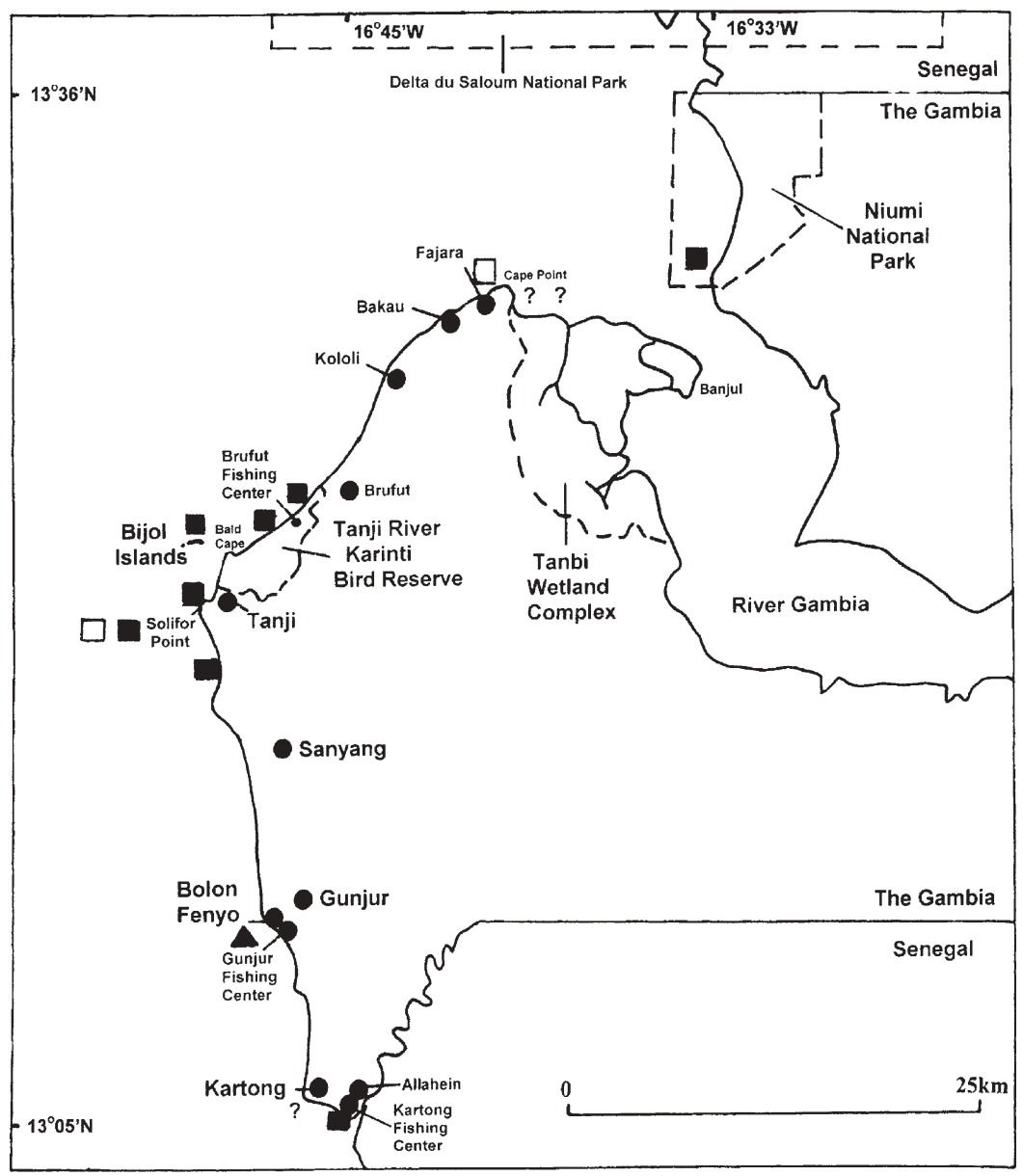

Fig. 1 Coastline of The Gambia, showing protected areas, major fishing centres and location of stranded turtles and skeletal remains. ( $\boldsymbol{\square}=$ green turtle; $\boldsymbol{\Delta}=$ olive ridley turtle; $\square=$ leatherback turtle; ? = unidentified turtle).

based mostly in the coastal area from Banjul south to Kololi. The only offshore islands are the Bijol Islands, which are two small deposits of sand, joined by a narrow sand spit, formed on shallow lateritic reefs. They are located $1.5 \mathrm{~km}$ off Bald Cape (Camara, 1998).

The mainland coastline comprises mostly sandy beaches backed by raised, ancient beaches. The beach substrates consist of yellowish fine to medium grained sands with a heavy mineral presence (ECOLAS, 2000). The ancient beaches form a series of broad, low ridges, parallel to the present shoreline, vegetated with coastal scrub and forest. In places there are low cliffs composed of laterite, with eroded boulders at their bases, which extend into the sea. In other areas the coastline consists of well-developed mangrove forests. Seawards the shallow continental shelf extends for a distance of $80 \mathrm{~km}$ (ECOLAS, 2000).

\section{Methods}

We determined the occurrence of turtle species in Gambian waters through personal observation and collation of old records, and newspapers and journals. Old stranding reports in files and reports of the Department of Parks and Wildlife Management were examined, as were turtle specimens held by the Department. All field work was conducted by LKB, CE, AJ and AC.

Straight line turtle carapace measurements were taken with calipers, and curved measurements with a flexible tape measure as per Bolten (1999). Standard straight carapace length (SCLn-t) and curved carapace length (CCLn-t), both taken from notch to tip, were measured from the anterior point at the mid-line (nuchal scute) to the posterior tip of the supracaudals. Carapace widths, both straight (SCW) and curved (CCW), were measured at the widest point of the carapace.

We also conducted informal interviews of 60 fishermen, 24 coastal residents and 8 fisheries officers, in which we asked questions about the marine turtles they had seen. To confirm species identification we used the illustrations from Pritchard \& Mortimer (1999), and questioned the informants about distinguishing taxonomic characters. During the interviews of the fishermen and coastal residents we asked about the relative 
abundance and distribution of each species, as well as seasonality of mating and egg laying. The 60 fishermen we interviewed included at least three senior fishermen and two junior fishermen at each of the eight major fishing centers. Interviews were conducted in English, Mandinka and Wolof, either by the authors or with the aid of fisheries officers at the sites, or by the fisheries officers themselves.

To evaluate the availability of nesting habitats, nesting distribution and seasonality we conducted beach surveys during 1999-2000, including monthly surveys of the Bijol Islands between September 1999 and October 2000 (Barnett et al., 2001). Profiles of the beach every $5 \mathrm{~km}$ along the $80 \mathrm{~km}$ of mainland coastline were documented, evaluating the characteristics of the offshore approach, the foreshore and the beach platform. We define suitable coastline as that having a sand beach platform sufficiently well developed to allow at least some nesting, along with a foreshore and an offshore approach that would not completely obstruct the emergence of a turtle from the sea (Mortimer \& Day, 1999). All marine turtle strandings and skeletal remains as well as any turtle tracks or body pits (depressions left in the sand by nesting turtles; Pritchard \& Mortimer, 1999) encountered during our beach surveys were recorded.

No surveys were conducted to assess the availability of turtle foraging habitat. However, relevant information was obtained during interviews with local fishermen, and from the literature. Information about threats and conservation measures was gathered during 76 of the informal interviews and by searching both the scientific and historical literature. In particular, we examined the libraries of local periodicals and newspapers.

\section{Results}

We obtained evidence for the presence of four marine turtle species in The Gambia. Forty-five confiscated green turtle Chelonia mydas carapaces were located at the Department of Parks and Wildlife Management, comprising a wide range of sizes (SCLn-t 26.7-91.0 cm, SCW $25.5-82.4 \mathrm{~cm}$ ). In addition, we found the remains of five stranded green turtles and 14 fragmentary green turtle remains (we were only able to identify those that included skull fragments). One of the stranded green turtles apparently had fibropapilloma disease, as diagnosed by JAM through a visual examination of the photographs of the dead turtle.

We located only one record of the leatherback turtle Dermochelys coriacea, in the files of the Department of Parks and Wildlife Management. This was a badly decomposed individual, of unknown sex, found $200 \mathrm{~m}$ south of Solifor Point on 26 April 1998 (CCLn- $t=152 \mathrm{~cm}$, $\mathrm{CCW}=107 \mathrm{~cm})$. We also located a leatherback turtle carapace in the garden of a bar owner in Fajara who indicated that it belonged to a dead turtle washed up during March 1999 on Fajara Beach (CCLn-t $=154 \mathrm{~cm}$, $\mathrm{CCW}=108 \mathrm{~cm}$ ).

During September 2000 a large freshly severed head of an olive ridley turtle Lepidochelys olivacea was confiscated by AMC from local fishermen at Gunjur Fishing Centre. The fishermen claimed that the turtle had drowned in their nets while they were fishing offshore. The rest of the turtle was not recovered.

We found only one record of the hawksbill turtle Eretmochelys imbricata, a single carapace of a specimen caught off the coast at Gunjur Fishing Centre during 1998 ( $\mathrm{SCLn}-\mathrm{t}=28.7 \mathrm{~cm}, \quad C C L n-\mathrm{t}=31 \mathrm{~cm}, \quad \mathrm{SCW}=22.3 \mathrm{~cm}$, $\mathrm{CCW}=26.8 \mathrm{~cm}$ ). We neither located any records nor made any personal observations of loggerhead turtle Caretta caretta. The localities of all turtle observations are shown on Fig. 1.

Our own observations are largely consistent with the views held by the fishermen and coastal residents. All interviewees stated that the green turtle was the most abundant marine turtle present. Of the fishermen interviewed, one third also identified hawksbill, olive ridley and leatherback turtles as being present in Gambian waters. Although we found no physical evidence or historic records of loggerhead turtles, $10 \%$ of the fishermen identified the species as being present, but in deeper waters away from the shore.

We sampled a total of 16 transects along the coast for suitability for turtle nesting. Based on our observations and using our definition of suitable, we estimate $75 \%$ of the coastline $(59.7 \mathrm{~km})$ to comprise habitat potentially suitable for turtle nesting. This includes the offshore islands of Bijol. The remaining $25 \%$ of the coastline, $1.3 \mathrm{~km}$ on the North Bank and $19 \mathrm{~km}$ on the South Bank, were characterized either by a narrow beach platform regularly inundated by high tide, by a beach having foreshore covered in large laterite boulders or laterite reefs extending to the foreshore, or by stretches of mangrove forest.

Interviews with local people revealed that turtles nest most frequently on the South Bank coast from the mouth of the Allehein River northwards to Sanyang. During our beach surveys we found seven recent green turtle body pits: six on Bijol Islands and one on the North Bank coast. Two additional nests to the west of Fajara were reported to the Department of Parks and Wildlife Management. The eggs of one of the nests was inspected by LKB and CE. It was found to contain green turtle eggs, and these were reburied. In addition, three nests were located on the beach within Tanji River (Karinti) Bird Reserve, with a fourth $1.5 \mathrm{~km}$ to the south of the Reserve. Large numbers of nests were reported on the beach a few 
hundred metres north of Bolon Fenyo, near Gunjur, by local residents. Only green turtle nests have been observed in The Gambia.

Local fishermen all agreed that the breeding season for turtles extends from June to November, with a peak from August to October. This was consistent with our own observations. Of the 13 recent green turtle body pits recorded during our study, we found one in June, four in September, five in October and three in November. False crawls of at least three individual green turtles were also found in June on the beach to the north of Kartong village.

Extensive seagrass beds have been documented off The Gambian coast (Murphy et al., 1997; Government of The Gambia, 1999a; Barnett et al., 2000). Our interviews with local people, especially artisanal fishermen, indicate that turtles forage in seagrass beds, and also in the vicinity of shallow rocky reefs that are a common feature close to shore.

\section{Discussion}

Our study, the first comprehensive survey of the marine turtles of the Gambian coastline, indicates the occurrence of green, hawksbill, leatherback and olive ridley turtles, and possibly also loggerhead turtles. Only the green turtle has been recorded to nest, apparently from June to November. Globally green, loggerhead and olive ridley turtles are categorized as Endangered on the IUCN Red List, and hawksbill and leatherback turtles as Critically Endangered (IUCN, 2002).

The green turtle, the most abundant species in The Gambia, is widespread in West Africa, and nests from Mauritania southwards to Cameroon (Fretey, 2001). Previous studies (Gruschwitz et al., 1991; Danso et al., 1997; Murphy et al., 1997; Camara, 1998; Government of The Gambia, 1999a; Barnett et al., 2000; ECOLAS, 2000) have also recorded this species as the most common. Fibropapilloma disease, characterised by cutaneous fibropapillomas and visceral fibromass (Herbst \& Jacobson, 1995) was identified in one stranded green turtle. This disease, which appears to be spreading in many populations (Herbst, 1994), has also been discovered on green turtles beached in the Saloum Delta, Northern Senegal, and the Gulf of Guinea, including São Tome, Cameroon and Gabon (J. Fretey, pers.comm).

The leatherback turtle is recorded along the entire Atlantic coast of Africa but appears to be rare in The Gambia. There is one previous record of the species (Fretey, 2001), and our study confirmed its presence. The olive ridley turtle has been recorded previously in The Gambia (Gruschwitz et al., 1991, Pauwels \& Meirte, 1996; Murphy et al., 1997) but appears to be rare. In West Africa, olive ridley nesting occurs south of The Gambia, between Guinea-Bissau and Angola (Fretey, 2001). The hawksbill turtle occurs only sporadically along the West African coast, although it may once have nested in The Gambia (Maigret, 1983). It had previously been recorded in The Gambia from confiscated carapaces (Gruschwitz et al., 1991), but the specimen observed in this study constitutes only the third record for the country. The loggerhead turtle occurs sporadically in the West African region and, although we were not able to confirm its presence in The Gambia, the species is known to nest in Guinea Bissau and Guinea and therefore is likely to occur in Gambian waters.

Threats to marine turtle populations in The Gambia include bycatch by artisanal fishermen and trawlers and nest predation by people, exacerbated by a lack of law enforcement. Suitable nesting habitat is being lost to natural erosion, illegal sand mining, and unregulated coastal development and tourism infrastructure. The only secure long-term hope for nesting turtles probably lies in the protected areas of Bijol Islands and Tanji River (Karinti) Bird Reserve. The highest turtle nesting concentrations, however, are thought to occur around Gunjur and Kartong, outside the reserves. Given the dense and rapidly rising human population in the country, additional protection at these latter areas is of paramount importance.

Nationally, the Wildlife Conservation Act of 1977 and the Biodiversity/Wildlife Policy and Regulation of 1999 protect marine turtles. Both prohibit the taking and killing of turtles and their eggs, as well as prohibiting the possession of eggs, meat or trophies of turtles (Government of The Gambia, 1977, 1999b). Despite this legislation turtles are still caught at sea and brought onto land to be butchered (Sieh, 1993; pers. obs.). Such activities prevail because of the combined lack of resources (both monetary and manpower) devoted to law enforcement, an unwillingness to enforce environmental and wildlife laws, and public ignorance of the laws.

The Department of Parks and Wildlife Management is the lead government agency in implementing national wildlife legislation and many of the international conventions to which The Gambia is a signatory, including the Bonn Convention on Migratory Species. In addition the Department also manages seven protected areas including two of which are on the coastline: Niumi National Park which includes all $11 \mathrm{~km}$ of the North bank, and Tanji River (Karinti) Bird Reserve, which includes $2 \mathrm{~km}$ of the southern coastline and the Bijol Islands. At a regional level, on 29 May 1999, The Gambia signed the Abidjan Memorandum of Understanding Concerning Conservation Measures for Marine Turtles of the Atlantic Coast of Africa (an agreement under the Convention on the Conservation of Migratory Species of Wild Animals) and has helped to prepare a regional conservation plan for marine turtles. The Gambia is also 
involved in the West Africa Marine Ecoregion subregional process initiated by WWF and IUCN. Nationally, the Department of Parks and Wildlife Management works together with the Department of Fisheries to sensitize people about the plight of marine turtles, although both Departments are handicapped by lack of resources. Recently, attempts have been made to publicize the law and the plight of marine turtles more fully, principally by using the national media (e.g. Barnett \& Emms, 2002, 2003; Drammeh, 2002). The Department of Parks and Wildlife Management has recently secured funding from the Global Environment Facility for integrated coastal and marine management. This project will collect national baseline information on marine turtles and cetaceans for the elaboration of a national conservation plan, as well as promoting public education and awareness. The Department of Parks and Wildlife Management will collaborate with the Department of Fisheries, fishing communities and a local NGO, the Gunjur Environmental Protection and Development Group, to conduct marine turtle monitoring activities along the coast.

These recent developments will enhance national sensitization and education about marine turtles. They will also encourage collaboration regionally and with overseas research and academic institutions to support a more thorough understanding of the biology and conservation status of marine turtles in The Gambia and West Africa. For conservation measures to be effective, however, such studies need to be implemented along with effective enforcement of national and international laws.

\section{Acknowledgements}

We gratefully acknowledge the Director of the Department of Parks and Wildlife Management, Dr A. Camara, for allowing this study to take place. We would also like to thank everyone who took part in interviews or who gave information regarding marine turtles in The Gambia. In particular we would like to thank all of the rangers at Tanji River (Karinti) Bird Reserve, especially Mr Ebou Jarju, who did a great deal to gather information along their section of the coast, the staff of Gunjur Environmental Protection and Development Group and Mrs Eva-Maria Minuth. We are also grateful to officers of the Department of Fisheries for their invaluable help, and to two anonymous referees who provided valuable comments on the paper.

\section{References}

Barnett, L.K. \& Emms, C. (2002) Focus on wildlife: what future for the marine turtle? Daily Observer, Thursday 27 June 2002. Bakau, The Gambia.
Barnett, L.K. \& Emms, C. (2003) Focus on wildlife: the Wildlife Law. Daily Observer, Thursday 13 March 2003. Bakau, The Gambia.

Barnett, L.K., Emms. C. \& Camara, A. (2001) The Birds of Bijol Island, Tanji River (Karinti) Bird Reserve, The Gambia. Bulletin of the African Bird Club, 8, 39-43.

Barnett, L.K., Sock, D \& Kuyateh, T. (2000) Ramsar Wetland Study, The Gambia. Management Plans for Niumi National Park, Bao Bolon Wetland Reserve and Tanbi Wetland Complex. Private Report Commissioned by the Department of State for Fisheries, Natural Resources and the Environment, Federal Republic of the Gambia and the Ramsar Bureau. Research and Development Unit, Department of Parks and Wildlife Management, Abuko, The Gambia.

Bolten, A. (1999) Techniques for measuring sea turtles. In Research and Management Techniques for the Conservation of Sea Turtles (eds K.L. Eckert, K.A. Bjorndal, F.A.

Abreu-Grobois \& M. Donnelly), pp. 110-114. IUCN/Species Survival Commission Marine Turtle Specialist Group Publication No. 4, Gland, Switzerland.

Camara, A. (1998) Draft Management Plan for Tanji and Bijol Islands Bird Reserve. Unpublished Report, Department of Parks and Wildlife Management, Abuko, The Gambia.

Danso, A., Dampha, A., Jammeh, B., Jallow, A. \& Murphy, P. (1997) Forest and wildlife resources. In State of the Environment Report - The Gambia (ed. N. Grey-Johnson), pp. 39-50. National Environment Agency, Banjul, The Gambia.

Drammeh, F. (2002) Focus on wildlife: conference on marine turtles ends. Daily Observer, Thursday 4 July 2002. Bakau, The Gambia.

ECOLAS (2000) Trade Gateway Project Environmental Impact Assessment Study. Draft Final Report, ECOLAS, Antwerp, Belgium.

Fatty, L., Gaye, M.S. \& Ceesay, K. (1997) Population, health and human resources. In State of the Environment Report - The Gambia (ed. N. Grey-Johnson), pp. 61-74. National Environment Agency, Banjul, The Gambia.

Fretey, J. (2001) Biogeography and Conservation of Marine Turtles of the Atlantic Coast of Africa. Convention on Migratory Species Technical Series Publication, No.6. UNEP/Convention on Migratory Species Secretariat, Bonn, Germany.

Government of The Gambia (1977) Wildlife Conservation Act, (Amended by Decree No. 90 of 1996). Government of The Gambia, Banjul, The Gambia.

Government of The Gambia (1999a) National Biodiversity and Strategy Action Plan. Government of The Gambia, Banjul, The Gambia.

Government of The Gambia (1999b) Biodiversity/Wildlife Policy and Regulation of 1999. Government of The Gambia, Banjul, The Gambia.

Gruschwitz, M., Lenz, S. \& Böhme W. (1991) Zur kenntnis der herpetofauna von Gambia (Westafrika). Teil 1: Einführung, frosclurche (Amphibia, Anura), schildkröten (Reptilia, Chelonia), krokodile (Crocodylia) und echsen (Sauria) Herpetofauna, 74, 13-22.

Herbst, L.H. (1994) Fibropapillomatosis of marine turtles. Annual Review of Fish Diseases, 4, 389-425.

Herbst, L.H. \& Jacobson, E.R. (1995) Diseases of marine turtles. In Biology and Conservation of Sea Turtles (ed. K.A. Bjorndal), pp. 593-596. Smithsonian Institution Press, Washington, DC, USA.

IUCN (2002) IUCN Red List of Threatened Species. IUCN, Gland, Switzerland [http:/ / www.redlist.org, accessed 16 October 2003]. 
Maigret, J. (1983) Repartition des tortes de mer sur les côtes ouest africanes. Le Bulletin de la Société de la Herpetologie Française , 28, 22-34.

Mortimer, J.A. \& Day, M. (1999) Sea turtle populations and habitats in the Chagos Archipelago. In Ecology of the Chagos Archipelago (eds C.R.C. Sheppard \& M.R.D. Seaward), pp. 159-172. Linnean Society Occasional Publications, 2.

Murphy, P.F., Fletchard, M.C., Barlow, C.R \& Njie, A. (1997) Ramsar Wetland Study, The Gambia. Private Report Commissioned by the Department of Parks and Wildlife Management under the Ministry of Fisheries and Natural Resources in collaboration with the Ramsar Bureau. Research and Development Unit, Department of Parks and Wildlife Management, Abuko, The Gambia.

Pauwels, O. \& Meirte, D. (1996) Contribution to the knowledge of the Gambian herpetofauna. British Herpetological Society Bulletin, 56, 27-34.

Pritchard, P.C.H. \& Mortimer, J.A. (1999) Taxonomy, external morphology, and species identification. In Research and Management Techniques for the Conservation of Sea Turtles (eds K.L. Eckert, K.A. Bjorndal, F.A. Abreu-Grobois \& M. Donnelly), pp. 21-38. IUCN/Species Survival Commission Marine Turtle Specialist Group Publication No. 4, Gland, Switzerland.

Sieh, R. (1993) Eight giant turtles languish on Bakau Beach - Banjul Declaration ignored. Daily Observer, Wednesday 7 April 1993. Bakau, The Gambia.

UNEP/CMS (1999a) Species Summary Sheets. International conference on the conservation of sea turtles of the Atlantic coast of Africa. Abidjan, Côte d'Ivoire, 25-29 May 1999. UNEP/CMS Secretariat, Bonn, Germany.

UNEP/CMS (1999b) Marine Turtle Conservation Status Report (for each Range State). International conference on the conservation of sea turtles of the Atlantic coast of Africa Abidjan, Côte d'Ivoire, 25-29 May 1999. UNEP/CMS Secretariat, Bonn, Germany.

\section{Biographical sketches}

Linda Barnett's research interests centre on the insects, herpetofauna, birds and mammals of The Gambia. As well as undertaking research she is involved in practical conservation and human capacity building for natural resource management in The Gambia

Craig Emms' main research interests concern the dragonflies, butterflies, amphibians, reptiles and mammals of the Gambia, especially bats. He is also heavily involved with raising national capacities through training and consultancies.

Alpha Jallow is the assistant director of the Department of Parks and Wildlife Management of The Gambia. He has recently been working to gather data on the cetaceans of Gambian waters.

Anna Mbenga Cham's research interests include cetaceans, marketing and gender issues.

Jeanne A. Mortimer has extensive international experience working with sea turtle biology and conservation, especially in the western Indian Ocean, South-east Asia and Central America. She is currently assisting the government of Seychelles with its sea turtle and giant tortoise conservation programmes. 